\title{
Karamenderes Ovası, Truva Bölgesi Sağ Sahil Fluviyal Topraklarının Sınıflandırılması
}

\author{
Timuçin EVEREST ${ }^{*}$ \\ Hasan ÖZCAN² \\ 'Gıda, Tarım ve Hayvancılık Bakanlığı, Ezine İlçe Müdürlüğü, Çanakkale \\ ${ }^{2}$ Çanakkale Onsekiz Mart Üniversitesi Ziraat Fakültesi, Toprak Bilimi ve Bitki Besleme Bölümü, Çanakkale
}

\author{
*Sorumlu yazar e-posta (Corresponding author e-mail) : timucineverest@gmail.com \\ Geliș tarihi (Received) : 05.08.2015 \\ Kabul tarihi (Accepted): 30.09.2015
}

\section{Öz}

Bu çalıșmada 3868,8 ha yüzölçümüne sahip Karamenderes Ovası' nın Truva bölümünde kalan sağ sahil arazilerinin detaylı toprak etüt ve haritalama çalıșması yapıımıștır. Çalıșmada temel kartoğrafik materyaller ve arazi gözlemleri kullanılarak toplam 14 profil açılmıștır. Arazi ve laboratuvar çalıșmaları sonucunda 7 toprak serisinin tanımlandığı çalıșmada topraklar, Toprak Taksonomisi (Soil Taxonomy) ve Dünya Toprak Kaynakları Referans Sistemi (WRB) sistemlerine göre sınıflandırılmıștır. Çalıșma sonucunda Arapkuyu, Çaybayırı, Karabağ ve Set serisi toprakları Typic_Ustifluvents; Paleosol özellikte olan Dümrek serisi Thapto_Typic Ustifluvents; Coraklar serisi toprakları ise Thapto_Mollic_Ustifluvents olarak sınıflandırılmıștır.

Anahtar Kelimeler: Fluviyal topraklar, sınıflandırma, toprak etüt, Truva

\section{Classification of Karamenderes' Plain, Troy Region Right Cost Fluvial Soils}

\begin{abstract}
In this study; Karamenderes Plain, Troy region right cost land's detailed soil survey and mapping work was carried out. In the study by using basic cartographic materials and land observations 14 profile were excavated. After laboratory and land work 7 soil series were desciribed. This series were classified in Soil Taxonomy and WRB systems. In the result of study soil series of Arapkuyu, Çaybayırı, Karabağ and Set were classified in Typic_Ustifluvents, which soils have paleosol properties were classified as Thapto_Typic_Ustifluvents; (Dümrek) and Thapto_Mollic_Ustifluvents; (Coraklar).
\end{abstract}

Key Words: Fluviyal soils, classification, soil survey, Troia

\section{Gíriș}

Tarımsal üretimin temel ve en önemli unsurlarından biri topraktır. İnsanların yașamını devam ettirebilmesi ve beslenme ihtiyacını karșılayabilmesi için tarımsal üretimin sürdürülebilir șekilde gerçekleștirilmesi gerekmektedir. Topraklardan optimum verimi alabilmek, toprakların yönetiminin sağlanması ile gerçekleștirilebilir. Toprakların uygun șekilde

yönetilebilmesi özelliklerinin ileri düzeyde bilinmesi ile mümkündür. Toprak etüt ve haritalama çalıșmaları ile toprak kaynaklarının özellikleri, sorunları, sınırları ve sınıfları belirlenmektedir.

Fluvisoller Latince "fluvius" nehir kelimesinden türetilmiștir. Fluvisoller bütün dünyada ve tüm iklim koșullarında ovalar, alüviyal yelpazeler, bataklıklar, deltalar v.b. periyodik olarak sular 
altında kalan alanlarda bulunurlar. Fluviyaller dünya üzerinde yaklașik 350 milyon ha alan kaplamaktadır. Bu alanların yarısından fazlası tropikal alanlar içinde yer almaktadır (WRB, 2006). Fluviyal malzemeler akarsuların farklı zamanlarda getirip depoladığı materyaller ile oluștuğu için çok yakın mesafeler içinde farklııklar gösterebilirler. Akarsular tașkın düzlüklerinde kendine yakın alanlarda tașıdığı daha büyük materyalleri bırakarak kaba bünyeli toprakları, kendisine daha uzak mesafede ise tașımıș olduğu daha küçük materyalleri bırakarak ince bünyeli toprakları oluștururlar. Bu topraklar fiziksel, kimyasal, morfolojik özellikleri, alüvyonun kaynaklandığı ana materyalin özelliği, tașınma ve birikme sırasında meydana gelen değișmeler sonucu karmașık bir olușum içermektedirler (Dengiz vd., 2010). Akgül ve Bașayiğit (2005), Süleyman Demirel Üniversitesi çiftlik arazisinde gerçekleștirdikleri detaylı toprak etüt ve haritalama çalıșması sonucunda 1500 dekar alan kaplayan arazide toplam 3 profil tanımlamıșlardır. Alüviyal yelpaze üzerinde olușmuș toprakları Vertic Xerofluvent ve Typic Xerofluvent alt grubu içinde sınıflandırılmıș ve 2 seri olușturularak 5 faz tanımlamıșlardır.

Saygın ve Dengiz (2013) Kızılırmak nehrinin tașıdığı malzemeler ile olușmuș alüviyal bir alanda detaylı toprak etüt ve haritalama çalıșması gerçekleștirmișlerdir. 1923,3 ha alanda gerçekleștirilen çalıșmada 9 profil tanımlanmıștır. 9 farklı serinin tanımlandığı çalıșmada topraklar toprak taksonomisine göre Entisol, Inceptisol ve Vertisol; FAO sınıflama sistemine göre ise, Regosols, Fluvisols, Gleysols, Cambisols ve Vertisols olarak sınıflandırılmıștır.

Truva Tarihi Milli Parkı' nın (TTMP) sağ sahilinde kalan arazilerde bugüne kadar herhangi bir toprak etüt ve haritalama çalıșması yapılmamıștır. Sadece 1960'lı yıllarda yapılan havza bazlı raporlar ve bunların iller bazında revize edilmiș envanterleri bulunmaktadır. Ancak mevcut bu raporlar çoğunlukla günümüz intiyaçlarına cevap verememektedir.

Bu çalıșmada Karamenderes Ovası́nın Truva Tarihi Milli Parkı sınırları içinde kalan fluviyal toprakların detaylı etüt ve haritalanması yapılarak, Toprak Taksonomisi (Soil Taxonomy, 2014) ve Dünya Toprak Kaynakları Referans Sistemi (WRB, 2014) sistemlerine göre sınıflandırılması gerçekleștirilmiștir.

\section{MATERYAL VE YÖNTEM}

\section{Materyal}

Çalıșma alanı $39^{\circ} 53^{\prime} 23^{\prime \prime}, 40^{\circ} 00^{\prime} 22^{\prime \prime}$ kuzey enlemleri ile $26^{\circ} 10^{\prime} 48^{\prime \prime}, 26^{\circ} 14^{\prime} 24^{\prime \prime}$ doğu boylamları arasında yer alan ve $3.868,8$ ha alanı kaplayan Karamenderes Ovası'nın Truva Tarihi Milli Parkı bölümünde kalan sağ sahil arazilerdir (Șekil 1).

Çanakkale ilinin uzun yıllar yıllık toplam yağıș ortalaması $625,9 \mathrm{~kg} / \mathrm{m}^{2}$ dır. Yörede ortalama yıllık sıcaklık $15,08{ }^{\circ} \mathrm{C}^{\prime}$, yıllık ortalama toprak sıcaklığı 50 cm' de $15,9^{\circ} \mathrm{C}$ dir. Bu veriler doğrultusunda çalıșma alanı topraklarının toprak nem rejimi ustic, toprak sıcaklık rejimi ise thermic'dir. Havzanın iklimi Thornthwaite iklim sınıflandırmasına göre C1, B'2,s2,b'3 yarı kurak az nemli, mezotermal, su fazlası kıș mevsiminde ve çok kuvvetli, yaz buharlașma oranı \% 53 olan iklim tipine girmektedir (MGM, 2014).

Truva çevresindeki jeolojik yapı beș ana kaya grubundan olușmaktadır. Metamorfik kristalin șist ve mermer alanın temel kayalarını olușturmaktadır. Temel kayaları ultramafik ve plütonik kayaçlar uyumsuz olarak üstlemektedir. Volkanik kayaçlar ise inceleme alanında yüzlek mostra veren plütonik ve ultramafik kayaçları da uyumsuz bir șekilde üstlemektedir. Volkanik kayaçlar; bazalt, dasit, riyolit, riyodasit, andesit ve piroklastik malzemeleri
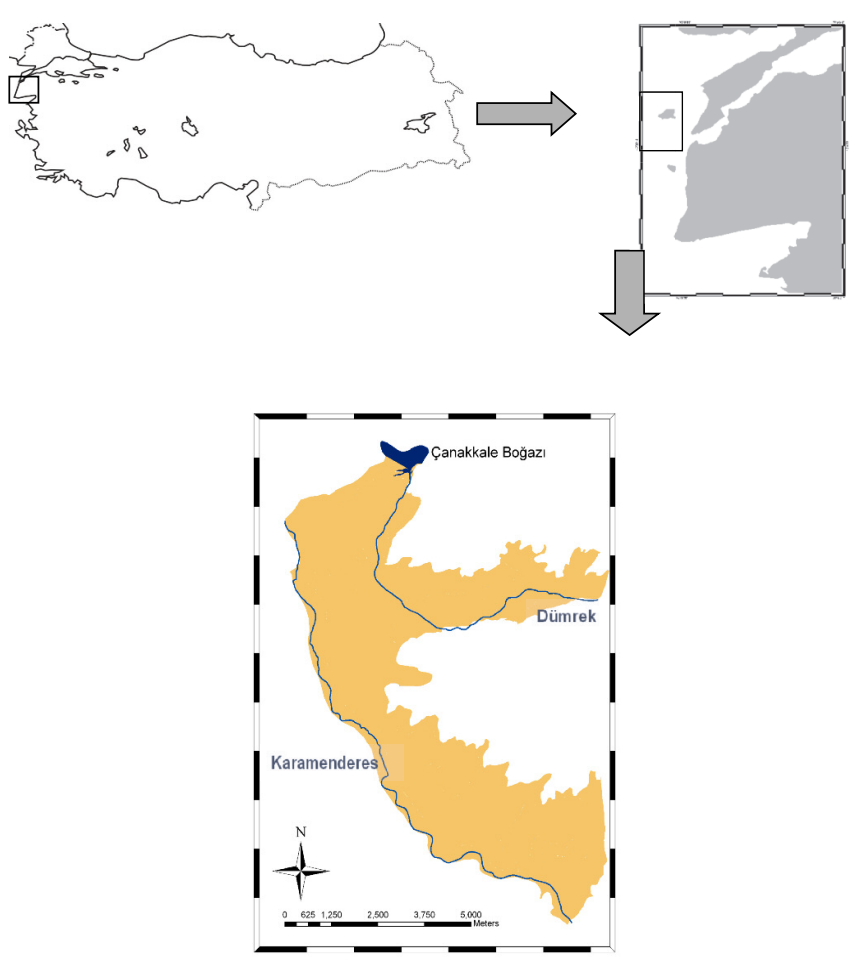

Șekil 1. Çalıșma alanı

Figure 1. Study area 


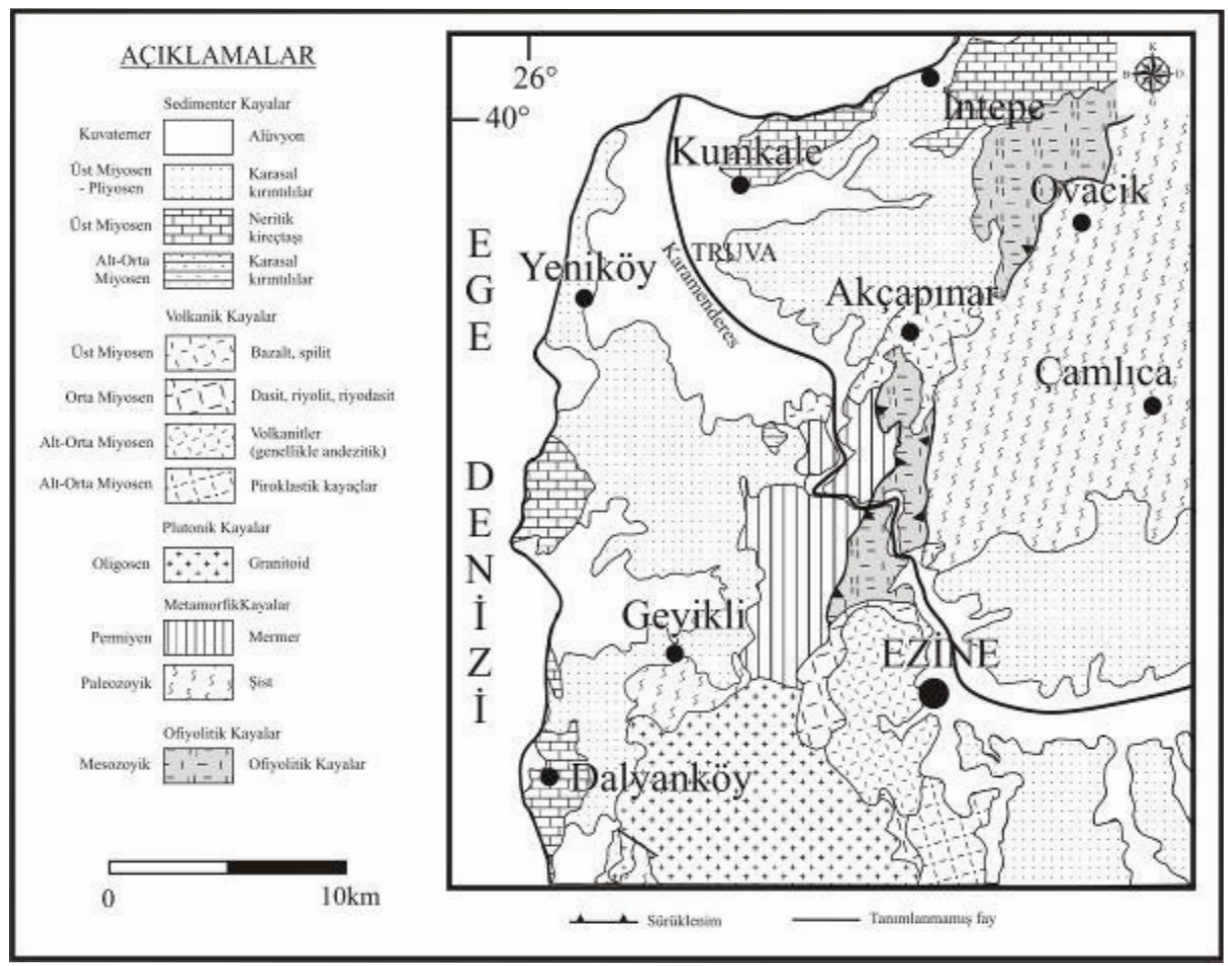

Șekil 2. Çalıșma alanı ve çevresi jeolojisi (Kayan, 2000)

Figure 2. Geology of study area and its around (Kayan, 2000)

içermektedir. Proje alanı ve çevresinde yüzlek mostra veren kum, kil ve kireçtașı gibi sedimenter kayaçlar ise, alandaki tüm birimleri üstlemektedir (Kayan, 2000). Șekil Z'de görüldüğü gibi inceleme alanındaki en genç birimler Ouaterner yașlı Karamenderes ve Dümrek Nehir' lerinin tașıdığı sedimentler üzerinde gelișen alüviyallerdir.

Bölgede yoğun olarak serin iklim tahılları, yonca, ayçiçeği, tohumluk ve silajlık mısır, kavun, karpuz, biber ile domates yetiștirilmekte Dümrek Vadisi' nin olumsuz iklim șartlarından korunaklı alanlarında ise bașlangıç așamasında meyvecilik faaliyeti bulunmaktadır.

\section{Yöntem}

Calıșma alanında profil noktalarını belirlemek amacıyla; 1/25.000 ölçekli sayısal topoğrafik harita paftaları, 1/100.000 ölçekli eski toprak haritası, jeoloji haritası verileri, SPOT uydusu görüntüsü ArcGIS 9.1 yazılımında üst üste çakıstırılmıș ve arazi gözlemleri ile ilișkilendirilerek toplam 14 profil noktası belirlenmiștir. Projenin büro çalıșması sırasında uydu görüntüsünün Erdas Imagıne 9.0 yazılımında ișlenmesi ile olası toprak sınırları belirlenmiștir. Eski toprak haritasında bulunan büyük toprak grupları ve jeoloji haritasındaki veriler ıșığında hangi bölgelerde değișim olabileceği konusunda fikir elde edilmiștir. Arazide açılan 14 profil çukurundan Soil Survey Staff (1999)'a göre örnekleme yapılmıș ve 74 bozulmuș toprak örneği alınmıștır. Laboratuvar analizlerinde bünye; Bouyoucos (1951), EC; (Richards, 1954) pH; (Richards 1954; Grewelling ve Peech, 1960), organik madde; (Smith ve Weldon, 1941), kireç; (Schlichting ve Blume, 1966), değișebilir katyonlar ve katyon değișim kapasitesi (U.S. Salinitiy Laboratory Staff, 1954) yöntemleri takip edilmiștir. Uydu görüntüsünün ișlenmesi ve yorumlanmasında Erdas Imagıne 9.0; topoğrafik ve jeoloji haritalarının sayısallaștırılmasında, eski toprak haritasının yorumlanmasında, toprak veri tabanı ve temel toprak haritasının olușturulmasında ArcGIS 9.1 yazılımı kullanılmıștır. Çalıșmada haritalama ölçeği 1/10.000 olarak belirlenmiștir.

\section{BULGULAR VE TARTIȘMA}

\section{Çalıșma Alanı Topraklarının Fiziksel, Kimyasal ve Morfolojik Özellikleri}

Detaylı etüt ve haritalama çalıșması kapsamında araștırma sahasında 14 profil tanımlanmıs ve birbirlerine benzerlik gösteren profiller aynı seriler içine dahil edilerek toplam 7 
seri tanımlanmıștır (Șekil 3). Çalıșma kapsamında her bir seri toprağının eğim, derinlik, üst toprak tekstürü, tuzluluk ve drenaj özelliklerine göre toplam 18 faz belirlenmiștir

Truva bölgesi sağ sahil toprakları fluviyal tașkın düzlükleri fizyoğrafik ünitesi içinde tanımlanmıștır. Fluviyal tașkın düzlükleri genç topraklar, gömülü profile sahip topraklar ve delta topraklarından olușmaktadır. Calıșma alanında Karamenderes Nehri' ne yakın bölgede olușmuș topraklar daha kaba bir bünyeye sahip iken Karamenderes Nehri'nden uzaklașıldığında parçacık boyutunun biraz daha küçülmesiyle daha ince bünyeli toprakların oluștuğu belirlenmiștir. Karamenderes ve Dümrek Nehirleri'nin birleșerek Çanakkale Boğazı' na döküldüğü noktada ise bir delta olușumu gözlenmekte ve bu bölgede delta toprakları olușmaktadır.

Dümrek Vadisinde tanımlanan Dümrek Çayı ve Çoraklar serisi toprakları ise gömülü profile sahip paleosol özelliktedirler. Paleosoller (gömülü toprak), oluștuğu dönemin yeryüzünü kaplayan topraklarıdır. Paleosoller genellikle gömülü haldedir ve bugünkü toprağın altında farklı tabakalar halinde bulunabilirler (Karaus, 1999).

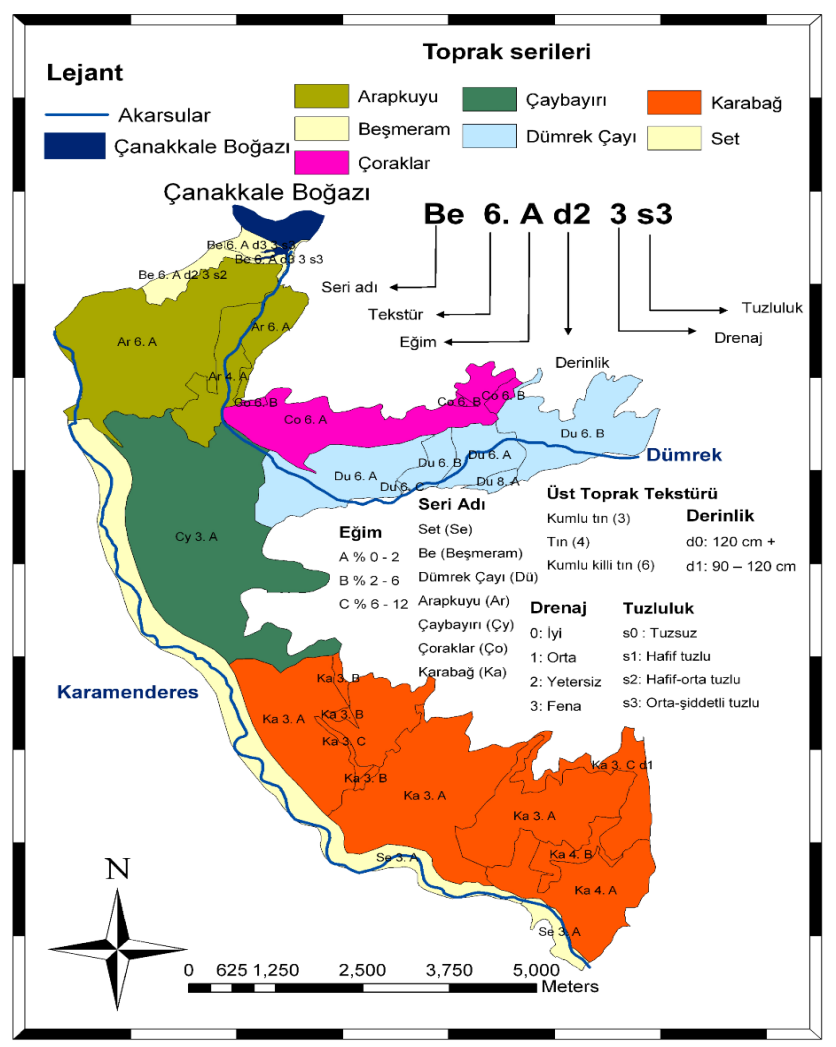

Șekil 3. Çalıșma alanı detaylı toprak haritası

Figure 3. Detailed soil map of study area

\section{Genç Topraklar}

Arapkuyu, Çaybayırı ve Karabağ serisine ait toprakların bazı fiziksel ve kimyasal analiz sonuçları Çizelge 1' de verilmiștir. Çalıșma alanı topraklarına ait bazı fiziksel ve kimyasal analiz sonuçları Arapkuyu serisi toprakları 5.918,82 da (\% 15,30) alanı kaplamaktadır. Karamenderes ve Dümrek Nehirleri' nin tașkın düzlüklerinde olușmuș seri topraklarının yükseklikleri 2,5-7,5 m arasında, eğimleri \% 0-1 arasında değișmektedir. Ap-Ad-2A2C-3C horizon dizilimine sahip toprakların yüzeydeki $A$ horizonunun hemen altında yanlıș toprak amenajmanından kaynaklanan sert pulluk altı katmanı bulunmaktadır. Arapkuyu serisinin topraklarının tekstürü killi tınlı olup en altta tanımlanan 3C horizonun da tınlı kumdur. Organik madde miktarı yüzeyde \% 2,37 iken derinlikle birlikte düzenli olarak azalmakta ve \% 0,29 değerine kadar düșmektedir. Profilin katyon değișim kapasitesi yüzeyde içerdiği kil ve organik madde miktarı sebebiyle $30,24 \mathrm{cmol} \mathrm{kg}^{-1}$ iken profil boyunca düzensiz olarak azalmaktadır. Profilin kireç içeriği \% 1,13 - \% 2,74 değeri arasında değișmektedir. Serinin $\mathrm{pH}$ değeri 7,337,87 arasındadır. Arapkuyu serisi topraklarının tuzluluk ve alkalilik açısından herhangi bir sorunu bulunmamaktadır.

Çaybayırı serisi toprakları toplam 7226,07 da $1 \%$ 18,67) yüzölçümüne sahiptir. Ap-A2-2A-2C1-2C2 horizon dizilimine sahip Çaybayırı serisi topraklarının en düșük seviyesi 5 m olup en yüksek noktası ise 15 metredir. Cok derin toprak profiline sahip seri toprakları düz ve düze yakın arazilerden (\% 0 0-2) olușmaktadır. Karamenderes Nehrine yakın mesafede olușmuș Çaybayırı serisi topraklarının tekstürü profil boyunca kumlu tındır. Organik madde içeriği yüzeyde \% 1,73 iken derinlikle beraber düzenli azalarak \% 0,35 değerine kadar düșmektedir. Katyon değișim kapasitesi yüzeyde $17,19 \mathrm{cmol} \mathrm{kg}^{-1}$ iken derinlikle beraber düzensiz azalmaktadır. Profilin kireç içeriği \% 3,07- 4,81 arasında değișmektedir. pH değeri yüzeyde 7,85 olup daha sonra profil içinde 8,0 seviyesinin üzerinde çוkmakta ve en altta bulunan 2C2 horizonunda 8,50 seviyesine ulașmakta, tuzluluk açısından herhangi bir problemi bulunmamaktadır.

Karabağ serisi toprakları Karamenderes Nehri'nin tașkın düzlüklerinde olușmuștur. Seri 11876,28 da $(\%$ 30,69) ile çalıșma alanı içinde en 
Çizelge 1 . Arapkuyu, Çaybayırı ve Karabağ serisine ait toprakların bazı fiziksel ve kimyasal analiz sonuçları

Table 1. Some physical and chemical analysis results of the Arapkuyu, Çaybayırı and Karabağ soils

\begin{tabular}{|c|c|c|c|c|c|c|c|c|c|c|c|c|c|}
\hline \multirow[t]{2}{*}{ Horizon } & \multirow{2}{*}{$\begin{array}{l}\text { Derinlik } \\
\text { (cm) }\end{array}$} & \multirow{2}{*}{$\mathrm{pH}$} & \multirow{2}{*}{$\begin{array}{c}E C \\
\left(d S m^{-1}\right)\end{array}$} & \multirow{2}{*}{$\begin{array}{l}\text { Kirec } \\
(\%)\end{array}$} & \multirow{2}{*}{$\begin{array}{r}O . M \\
(\%)\end{array}$} & \multirow{2}{*}{$\begin{array}{c}\text { KDK } \\
\left(\mathrm{cmol} \mathrm{kg}^{-1}\right)\end{array}$} & \multicolumn{3}{|c|}{$\begin{array}{l}\text { Değișebilir katyonlar } \\
\left(\mathrm{cmol} \mathrm{kg}{ }^{-1}\right)\end{array}$} & \multirow{2}{*}{$\begin{array}{l}\text { Kil } \\
(\%)\end{array}$} & \multirow{2}{*}{$\begin{array}{l}\text { Silt } \\
(\%)\end{array}$} & \multirow{2}{*}{$\begin{array}{l}\text { Kum } \\
(\%)\end{array}$} & \multirow{2}{*}{$\begin{array}{l}\text { Bünye } \\
\text { Sinıfi }\end{array}$} \\
\hline & & & & & & & $\mathrm{Na}$ & $\mathrm{K}$ & $\mathrm{Ca}+\mathrm{Mg}$ & & & & \\
\hline \multicolumn{14}{|c|}{ Arapkuyu serisi } \\
\hline Ap & $0-10$ & 7,33 & 0,31 & 1,13 & 2,37 & 30,24 & 0,25 & 0,68 & 29,31 & 28,88 & 31,63 & 39,49 & $\mathrm{CL}$ \\
\hline Ad & $10-28$ & 7,78 & 0,72 & 1,29 & 1,90 & 31,15 & 0,27 & 0,66 & 30,22 & 34,87 & 27,53 & 37,60 & $\mathrm{CL}$ \\
\hline $2 \mathrm{~A}$ & $28-42$ & 7,77 & 0,86 & 1,45 & 1,39 & 30,10 & 0,25 & 0,65 & 27,74 & 36,99 & 31,64 & 31,37 & $\mathrm{CL}$ \\
\hline $2 \mathrm{C}$ & $42-99$ & 7,87 & 0,67 & 2,74 & 0,72 & 29,34 & 0,29 & 0,64 & 26,98 & 30,88 & 31,61 & 37,50 & $\mathrm{CL}$ \\
\hline $3 C$ & $99-160$ & 7,78 & 0,43 & 1,28 & 0,29 & 11,21 & 0,18 & 0,58 & 9,92 & 8,59 & 10,04 & 81,37 & LS \\
\hline \multicolumn{14}{|c|}{ Çaybayırı serisi } \\
\hline Ap & $0-19$ & 7,85 & 0,12 & 4,52 & 1,73 & 17,19 & 0,10 & 0,88 & 16,20 & 10,74 & 21,08 & 68,18 & $S L$ \\
\hline$A 2$ & $19-41$ & 8,01 & 0,10 & 3,84 & 1,09 & 13,21 & 0,08 & 0,81 & 12,03 & 8,60 & 22,84 & 68,56 & $S L$ \\
\hline $2 \mathrm{~A}$ & $41-66$ & 8,33 & 0,95 & 4,81 & 0,83 & 16,26 & 0,09 & 0,86 & 15,12 & 10,31 & 19,29 & 70,40 & SL \\
\hline $2 \mathrm{Cl}_{1}$ & $66-99$ & 8,14 & 0,18 & 4,64 & 0,32 & 12,36 & 0,06 & 0,75 & 11,55 & 6,61 & 16,85 & 76,54 & SL \\
\hline $2 C 2$ & 99-140 & 8,50 & 0,41 & 3,07 & 0,35 & 12,12 & 0,06 & 0,72 & 11,34 & 6,25 & 17,23 & 76,52 & $S L$ \\
\hline \multicolumn{14}{|c|}{ Karabağ serisi } \\
\hline Ap & $0-23$ & 7,69 & 0,09 & 3,17 & 1,12 & 29,72 & 0,15 & 0,52 & 29,05 & 5,66 & 43,42 & 50,92 & SL \\
\hline$A C$ & $23-55$ & 7,82 & 0,08 & 4,27 & 0,87 & 26,71 & 0,14 & 0,48 & 25,04 & 3,65 & 63,13 & 33,22 & SiL \\
\hline $\mathrm{Cl}$ & $55-89$ & 7,93 & 0,08 & 4,28 & 0,73 & 28,15 & 0,15 & 0,50 & 26,40 & 5,66 & 49,86 & 44,48 & SL \\
\hline $\mathrm{C2}$ & $89-165$ & 7,92 & 0,08 & 5,07 & 0,52 & 23,36 & 0,12 & 0,44 & 21,88 & 3,66 & 53,90 & 42,44 & SiL \\
\hline
\end{tabular}

fazla alana sahip olup profilleri çok derindir Karabağ serisi toprakları 10-25 m kotu arasında yer almaktadır. Ap-AC-C1-C2 horizon dizilimine sahip seri topraklarının pH değerleri profil boyunca 7,697,92 arasında değișmektedir. Karabağ serisi topraklarının yüzey tekstürü kumlu tın olup yüzey altındaki horizonlarda sırasıyla siltli tın, kumlu tın, siltli tın șeklinde değișim göstermektedir. Organik madde yüzeyde \% 1,12 değerinde olup derinlere doğru düzenli șekilde azalarak en altta bulunan C2 horizonunda \% 0,52 değerine düșmektedir. Toprakların katyon değișim kapasitesi yüzeyde 29,72 cmol kg-1 değerinde olup derinlikle beraber düzensiz azalmaktadır. Kireç içeriği yüzeyden derine doğru \% 3,17- 5,07 değerleri arasında değișim göstermektedir. AC ve Cl horizonlarında sırasıyla orta yoğun ve az yoğun kireç cepleri görülmektedir. Tuzluluk ve alkalilik açısından herhangi bir problemi bulunmamaktadır.

Set serisi toprakları Karamenderes Nehri'nin yatağı boyunca yayılım göstermekte ve Karamenderes Nehri' ne en yakın mesafede olușan toprakları içirmektedir. Toplam 4354,02 da 1\% $11,26)$ yüzölçümüne sahiptir. Karamenderes Nehri'nin tașıyıp depoladığı materyaller ile olușmuș topraklar Ap-C-2A-2C 1-2C2-3A-3C horizon dizilimine sahiptir. Set serisi topraklarının en yüksek noktası 26 $m$ olup, seri topraklarının kuzey bölgelerinde bulunan arazilerinde yükseklik $5 \mathrm{~m}$ kotuna kadar düșmektedir. Seri toprakları \% 0-2 eğim değerine sahiptir. Set serisi topraklarında baskın tekstür kumlu tın'dır. Karamenderes Nehri'ne yakın mesafede olușmuș topraklar kaba bünyelidir. Organik madde profil boyunca düșük miktarda olup \% 0,01 - \% 0,48 arasında değișim göstermektedir. Profilde derinlere doğru inildiğinde organik madde miktarı azalmaktadır. Seri topraklarının katyon değișim kapasitesi yüzeyde 15,83 cmol kg-1 olup derinlikle beraber düzensiz olarak değișim göstermektedir. Profilin $\mathrm{pH}$ değeri 7,65-7,88 arasında değișirken tuzluluk ve alkalilik açısından bir risk tașımamaktadır (Çizelge 2). 
Çizelge 2. Set ve Çoraklar serilerine ait toprakların bazı fiziksel ve kimyasal analiz sonuçları

Table 2. Some physical and chemical analysis results of the Set and Coraklar soils

\begin{tabular}{|c|c|c|c|c|c|c|c|c|c|c|c|c|c|}
\hline \multirow[t]{2}{*}{ Horizon } & \multirow{2}{*}{$\begin{array}{l}\text { Derinlik } \\
(\mathrm{cm})\end{array}$} & \multirow{2}{*}{$\mathrm{pH}$} & \multirow{2}{*}{$\begin{array}{c}E C \\
\left(\mathrm{dS} \mathrm{m}^{-1}\right)\end{array}$} & \multirow{2}{*}{$\begin{array}{l}\text { Kireç } \\
(\%)\end{array}$} & \multirow{2}{*}{$\begin{array}{r}O . M \\
(\%)\end{array}$} & \multirow{2}{*}{$\begin{array}{l}\text { KDK } \\
\left(\mathrm{cmol}^{-1}\right. \\
\left.\mathrm{kg}^{-1}\right)\end{array}$} & \multicolumn{3}{|c|}{$\begin{array}{c}\text { Değișebilir katyonlar } \\
(\mathrm{cmol} \mathrm{kg})\end{array}$} & \multirow{2}{*}{$\begin{array}{l}\text { Kil } \\
(\%)\end{array}$} & \multirow{2}{*}{$\begin{array}{l}\text { Silt } \\
(\%)\end{array}$} & \multirow{2}{*}{$\begin{array}{l}\text { Kum } \\
(\%)\end{array}$} & \multirow{2}{*}{$\begin{array}{c}\text { Bünye } \\
\text { Sinıfı }\end{array}$} \\
\hline & & & & & & & $\mathrm{Na}$ & $\mathrm{K}$ & $\mathrm{Ca}+\mathrm{Mg}$ & & & & \\
\hline \multicolumn{14}{|c|}{ Set serisi } \\
\hline Ap & $0-15$ & 7,65 & 0,33 & 2,32 & 0,48 & 15,83 & 0,10 & 0,21 & 15,52 & 14,04 & 15,33 & 70,63 & SL \\
\hline C & $15-27$ & 7,75 & 0,28 & 2,16 & 0,31 & 12,03 & 0,09 & 0,19 & 11,41 & 12,01 & 13,29 & 74,70 & SL \\
\hline $2 \mathrm{~A}$ & $27-41$ & 7,72 & 0,27 & 3,09 & 0,31 & 14,16 & 0,09 & 0,20 & 13,03 & 14,05 & 13,33 & 72,62 & $\mathrm{SL}$ \\
\hline $2 \mathrm{Cl}$ & $41-56$ & 7,80 & 0,23 & 2,85 & 0,22 & 13,77 & 0,09 & 0,19 & 13,11 & 13,68 & 14,63 & 71,69 & SL \\
\hline $2 C 2$ & $56-91$ & 7,87 & 0,16 & 2,78 & 0,01 & 8,02 & 0,07 & 0,12 & 7,45 & 8,01 & 1,28 & 90,71 & $S$ \\
\hline $3 A$ & $91-113$ & 7,83 & 0,20 & 2,63 & 0,05 & 22,51 & 0,11 & 0,35 & 21,69 & 20,09 & 19,37 & 60,54 & $\mathrm{SCL}$ \\
\hline $3 C$ & $113+$ & 7,88 & 0,17 & 1,70 & 0,18 & 14,69 & 0,10 & 0,20 & 13,82 & 14,06 & 15,35 & 70,59 & $S L$ \\
\hline \multicolumn{14}{|c|}{ Coraklar serisi } \\
\hline Ap & $0-24$ & 7,83 & 0,80 & 7,88 & 3,10 & 37,00 & 0,24 & 0,59 & 36,17 & 38,01 & 30,24 & 31,75 & $\mathrm{CL}$ \\
\hline$A 2$ & $24-41$ & 7,76 & 0,35 & 9,88 & 3,12 & 36,15 & 0,24 & 0,58 & 34,12 & 39,04 & 35,50 & 25,46 & $\mathrm{CL}$ \\
\hline$C$ & $41-63$ & 8,05 & 0,23 & 10,71 & 1,46 & 44,58 & 0,36 & 0,67 & 41,86 & 45,20 & 31,39 & 23,41 & C \\
\hline$A b$ & $63-76$ & 8,07 & 0,25 & 10,75 & 1,41 & 38,23 & 0,34 & 0,60 & 35,41 & 40,26 & 29,38 & 30,36 & C \\
\hline Bwb & 76-99 & 8,06 & 0,24 & 10,82 & 1,26 & 39,16 & 0,32 & 0,62 & 36,69 & 42,18 & 39,41 & 18,41 & $C$ \\
\hline $\mathrm{Cl}$ & $99-133$ & 8,00 & 0,31 & 11,38 & 1,12 & 28,92 & 0,21 & 0,47 & 26,82 & 31,71 & 28,95 & 39,34 & $\mathrm{CL}$ \\
\hline $2 C 2$ & $133-152$ & 8,00 & 0,33 & 13,59 & 0,58 & 26,14 & 0,19 & 0,44 & 23,54 & 29,59 & 16,74 & 53,67 & $\mathrm{SCL}$ \\
\hline
\end{tabular}

\section{Gömülü Profile Sahip Topraklar}

Çoraklar (Ço) serisi toprakları Dümrek Çayı' nın tașkın düzlüklerinde olușmuș çok derin topraklardır. Toplam 2831,82 da (\% 7,32) alan kaplayan seri toprakları \% 0-2 eğimlidir. Serinin en düșük seviyesi 7,5 m ve en yüksek seviyesi 20 metredir. Ap-A2-CAb-Bwb-C1-2C2 horizon dizilimine sahip Çoraklar serisi toprakları paleosol özellikte olup, önceki zamanlarda gelișmiș olgun bir toprağın (Ab-Bwb-C12C2) üzerini fluviyal malzemenin (Ap-A2-C) örtmesi ile olușmuștur. Üstte bulunan genç toprağın Ap horizonunda $\mathrm{pH}$ değeri yüzeyde 7,83 olup derinlikle beraber düzenli olarak artarak C horizonunda 8,05'e yükselmektedir. Tekstür yüzeyde killi tın olup $A Z^{\prime}$ de killi tın ve $C$ horizonunda ise kildir. Organik madde Ap horizonunda \% 3, 10 olup A2'de \% 3, 12 iken Ab horizonunda \% 1,46'dır. Kireç miktarı yüzeyde \% 7,88 iken Ab horizonuna kadar düzenli artmakta ve \% 10,71 değerine ulașmaktadır. Altta bulunan olgun toprağın üstteki ve alttaki horizona göre renk ve strüktür gelișiminin gözlendiği bir cambic (Bwb) horizonu bulunmaktadır. $\mathrm{pH}$ değeri Ab'de 8,07 olup, derinlikle beraber düzenli azalarak 8,00 değerine düșmektedir. Kireç Ab horizonunda \% 10,75 olup, derinlikle beraber düzenli artarak \% 13,59 seviyesine ulașmaktadır. Tekstür Ab-Bwb horizonunda killi iken Cl'de killi tın ve 2C2'de kumlu killi tındır. Coraklar serisi topraklarında kil miktarının \% 40 civarında olmasına karșın, vertik özellikleri karșilayacak karakteristikleri içermemektedir (Çizelge 2).

Dümrek Çayı serisi Dümrek Çayı' nın tașkın düzlüklerinde olușmuș olup, Ap-A2-AC-C-Ab-Btb-Bgb șeklinde horizon dizilimli Paleosol özellikte topraklardır. Dümrek Çayı' nın farklı zamanlarda getirmiș olduğu malzemelerin daha önceki zamandan olușmuș toprak gövdesini örtmesi ile olușmuștur. Seri toprakları 5.709, 14 da $(\%$ 14,75) alan kaplamaktadır. Seri toprakları 7,5-32 m yükseklik değerleri arasında yer almaktadır. Genellikle düz arazilerden olușan topraklarda eğim \% 0-2'dir. Üstte bulunan genç toprağın Ap-A2 ve AC horizonlarının tekstürü killi tın olup C'de ise kumlu killi tındır. Organik madde yüzeyde \% 1,84 olup, derinlikle beraber düzensiz azalarak \%1,20 değerine inmektedir. Kireç içeriği Ap horizonunda \% 9,31 olup düzensiz değișmekte ve C horizonunda \% 9,77 değerini bulmaktadır. Altta bulunan eski toprağın Ab 
Çizelge 3. Dümrek Çayı ve Beșmeram serilerine ait toprakların bazı fiziksel ve kimyasal analiz sonuçları

Table 3. Some physical and chemical analysis results of the Dümrek Cayı and Beșmeram soils

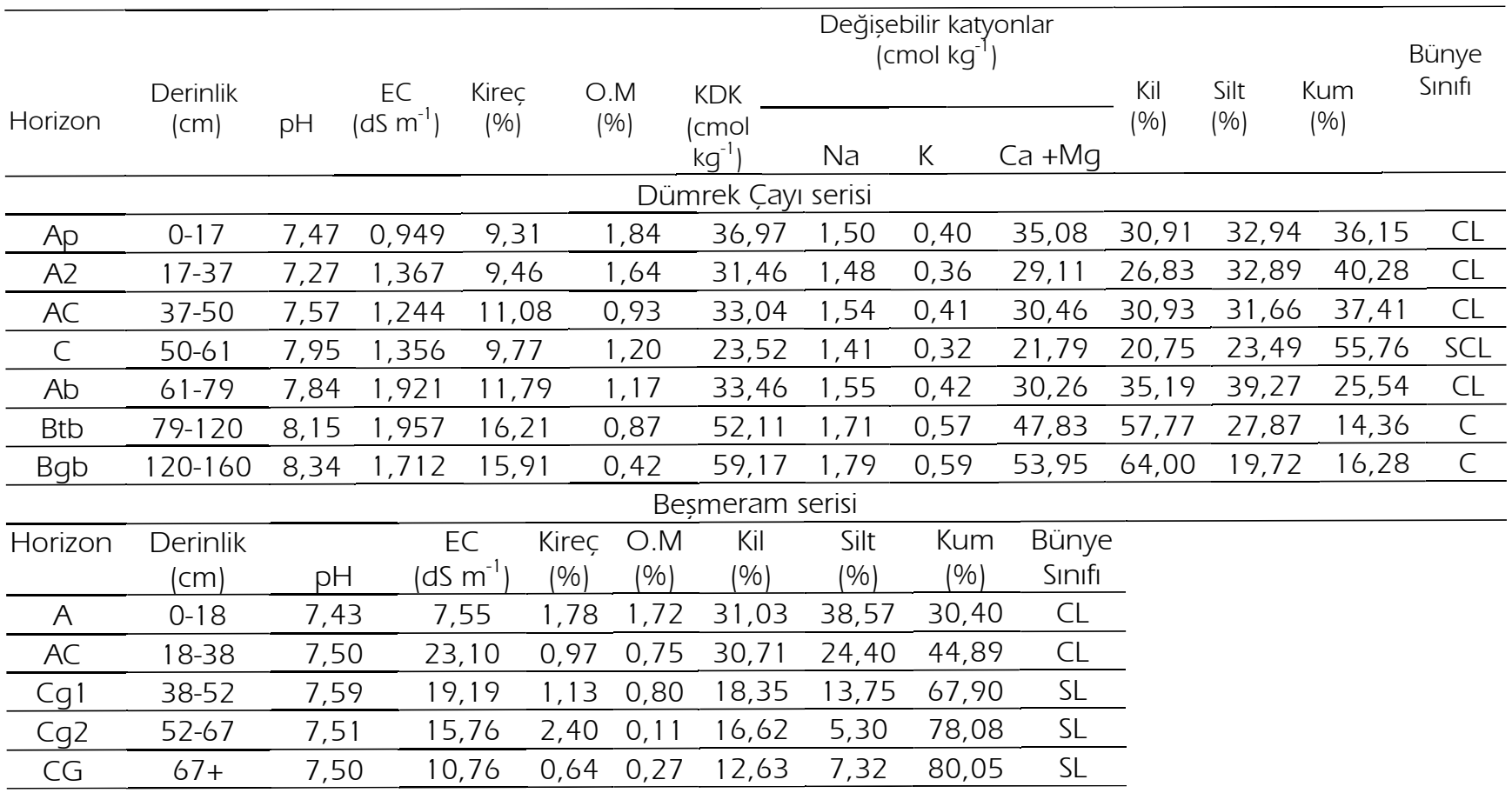

horizonunda tekstür killi tın iken, Btb horizonunda ve en altta bulunan Bgb horizonunda kil miktarının sırasıyla \% 57,77 ve \% 64'e yükselmesinden dolayı bünye kildir.

Btb horizonunda taban suyu faaliyeti nedeniyle çok seyrek pas lekeleri görülmektedir. pH değeri Ab horizonunda 7,84 olup, derinlikle beraber düzenli artmakta ve 8,35 değerine ulașmaktadır. Kireç miktarı Ab horizonunda \% 11,79 olup düzensiz değișmekte ve en altta bulunan horizonda \% 16,21 değerini bulmaktadır. Organik madde içeriği Ab horizonunda \%1,17 değerinde iken, derinlerde düzensiz azalarak \% 0,42 değerine kadar değișim göstermektedir (Çizelge 3).

\section{Delta Toprakları}

Beșmeram serisi toprakları; Karamenderes ve Dümrek Nehir' lerinin tașımıș olduğu materyalleri Çanakkale Boğazı' na döktüğü noktada denizi doldurması ile olușmuștur. Delta ağzında gelișen seri toprakları A-AC-Cg1-Cg2-CG horizon dizilimli olup, toplam 775,35 da alan kaplamaktadır. Deniz seviyesinde $(0-2,5 \mathrm{~m})$ bulunan Beșmeram serisi topraklarında eğim \% 0-1 oranındadır. Profilde 67 $\mathrm{cm}^{\prime}$ de bulunan taban suyu nedeniyle AC horizonundan itibaren hafif pas lekeleri ve derinlerde yoğun pas lekeleri ile birlikte kuvvetli gleyleșme görülmektedir. Fena drenajlı olan seri topraklarında tuz miktarı denizsel etki nedeni ile profil boyunca çok yüksektir. 7,55 dS $\mathrm{m}^{-1}$ olan EC değeri deniz ve delta etkisi ile profil boyunca düzensiz artarak 23,10 dS $\mathrm{m}^{-1}$ seviyesine yükselmektedir. Profilin üst toprak tekstürü killi tın iken, derinlerde kil miktarının azalması ve kum miktarındaki belirgin artıș ile tekstür kumlu tındır. Organik madde miktarı yüzeyde \% 1,72 seviyesinde iken profil boyunca düzensiz olarak azalarak derinlerde \% 0,11 seviyesine düșmektedir. $\mathrm{pH}$ değeri 7,43-7,51 arasında değișirken, kireç miktarı \% 0,64-2,40 arasında değișim göstermektedir (Çizelge 3). Aktif bitkisel üretim faaliyetinin yapılamadığı arazilerde genelde halofit (tuzcul) bitkiler hakim konumdadır. Tuz miktarının bitkisel üretimi engelleyecek düzeyde olması sebebi ile, bölgedeki terk konumundaki araziler doğal hayat olarak kullanılmaktadır.

\section{Calıșma Alanı Topraklarının Sınıflandırılması}

Calıșma alanı toprakları toprak taksonomisi, Toprak Taksonomisi (Soil Taxonomy, 2014) ve Dünya Toprak Kaynakları Referans Sistemi (WRB, 2014) sınıflandırma sistemlerine göre sınıflandırılmıștır. Çizelge 4' de görüldüğü gibi seriler Toprak Taksonomisine göre; Entisol ordosunda sınıflandırılmıștır. WRB sınıflama sistemine göre ise, topraklar Fluvisols ve Gleysols olarak sınıflandırılmıștır. 
Çizelge 4. Çalıșma alanı topraklarının Toprak Taksonomisi ve Dünya Toprak Kaynakları Referans Sistemi 'ne göre sınıflandıııması

Table 4. Classification of the study area soils according to Soil Taxonomy and WRB

\begin{tabular}{|c|c|c|c|c|c|c|}
\hline \multirow[b]{2}{*}{ No } & \multirow[b]{2}{*}{ Seri Adı } & \multicolumn{4}{|c|}{ Toprak Taksonomisi (2014) } & \multirow[t]{2}{*}{ WRB (2014) } \\
\hline & & Ordo & $\begin{array}{c}\text { Alt } \\
\text { Ordo }\end{array}$ & Büyük Grup & Alt Grup & \\
\hline 1 & Set & Entisol & Fluvents & Ustifluvents & Typic_Ustifluvents & Haplic_Fluvisols (Eutric) \\
\hline 2 & Dümrek & Entisol & Fluvents & Ustifluvents & Thapto_Typic_Ustifluvents; & $\begin{array}{c}\text { Haplic_Fluvisols (Calcaric, Eutric) } \\
\text { Over_Haplic_Luvisols }\end{array}$ \\
\hline 3 & Beșmeram & Entisol & Aquents & Fluvaquents & Typic_Fluvaquents & $\begin{array}{c}\text { Endosalic_Luvic_Gleysols } \\
\text { (Calcaric, Eutric, Greyic, Drainic) }\end{array}$ \\
\hline 4 & Arapkuyu & Entisol & Fluvents & Ustifluvents & Typic_Ustifluvents & Haplic_Fluvisols (Eutric) \\
\hline 5 & Çaybayııı & Entisol & Fluvents & Ustifluvents & Typic_Ustifluvents & Haplic_Fluvisols (Eutric) \\
\hline 6 & Karabağ & Entisol & Fluvents & Ustifluvents & Typic_Ustifluvents & $\begin{array}{l}\text { Haplic_Fluvisols (Calcaric, Eutric, } \\
\text { Siltic) }\end{array}$ \\
\hline 7 & Çoraklar & Entisol & Fluvents & Ustifluvents & Thapto_Mollic_Ustifluvents; & $\begin{array}{c}\text { Mollic_Fluvisols (Calcaric, Eutric) } \\
\text { Over_Fluvic_Cambisols }\end{array}$ \\
\hline
\end{tabular}

Arapkuyu serisi Toprak Taksonomisine göre; Typic_Ustifluvents, WRB'ye göre; Haplic_Fluvisols (Eutric), Çaybayırı serisi Toprak Taksonomisine göre; Typic_Ustifluvents, WRB'ye göre; Haplic_Fluvisols (Eutric), Karabağ serisi Toprak Taksonomisine göre; Typic_Ustifluvents, WRB'ye göre; Haplic_Fluvisols (Calcaric, Eutric, Siltic), Set serisi Toprak Taksonomisine göre; Typic_Ustifluvents, WRB'ye göre; Haplic_Fluvisols (Eutric), Beșmeram serisi Toprak Taksonomisine göre; Typic_Fluvaquents, WRB'ye göre; Endosalic_Luvic_Gleysols (Calcaric, Eutric, Greyic, Drainic), Coraklar serisi Toprak Taksonomisine göre; Thapto_Mollic_Ustifluvents; WRB'ye göre; Mollic_Fluvisols (Calcaric, Eutric) Over_Fluvic_Cambisols, Dümrek Çayı serisi Toprak Taksonomisine göre; Thapto_Typic_Ustifluvents, WRB'ye göre; Haplic_Fluvisols (Calcaric, Eutric) Over_Haplic_Luvisols olarak sınıflandırılmıștır.

\section{SONUC̣LAR}

Truva Bölgesi sağ sahil toprakları toplam 3868,8 ha yüzölçümüne sahiptir. Çalıșma alanının $\%$ 97, 99' unda sulu tarım yapıımaktadır. Çalıșma alanı toprakları çok verimli olmasına karșın bazı problemleri içermektedir. Gerçekleștirilecek amenajman yöntemleri ile söz konusu arazilerin sürdürülebilirliği sağlanabilecektir. Set serisi toprakları Karamenderes Nehri' ne en yakın mesafede meydana gelen toprakları içermektedir. Bu topraklar içerdikleri fazla miktarda kum nedeniyle verimlilik açısından düșük potansiyele sahiptir. Bu topraklarda istenilen verimi almak ve sürdürülebilirliği sağlamak için, mutlaka toprak analizi sonuçlarına göre gübreleme yapılmalıdır. Taneciklerin birbirine olan bağlanmalarının ve organik madde miktarının arttırılması için hayvan gübresi ile yeșil gübre uygulamasına önem verilmelidir. Sulama ișleminde basınçlı sulama sistemleri kullanılarak bitki kök bölgesine sık ve az miktarlarda su verilmelidir. Arapkuyu serisi topraklarında yüzeyin hemen altında sıkıșmıș bir katman bulunmaktadır. Bitkilerin köklerinin hareketi ile besin maddesi ve suyun alımını olumsuz yönde etkileyen sıkıșmıș katmanın derin sürüm ile kırılması gerekmektedir. Çalıșma alanının en kuzeyinde bulunan Beșmeram serisi toprakları Karamenderes ve Dümrek Nehirleri' nin olușturduğu deltanın üzerinde yer almaktadır. Bu alanlarda denizsel etki nedeniyle tuz içeriği yüksek düzeydedir. $7,55 \mathrm{dS} \mathrm{m}^{-1}$ olan tuz değeri derinlerde $23,10 \mathrm{dS} \mathrm{m}^{-1}$ değerine kadar yükselmekte ve bu araziler mera ve doğal hayat alanı olarak kullanılmaktadır. Serinin güneyinde bulunan bazı alanlarda bitkisel üretim yapılmaktadır. Bu alanlarda tuzluluktan kaynaklanan olumsuzluklar nedeniyle verimde azalmalar yașanmaktadır. Bu tarım alanlarında bitkisel üretim yapılamaya devam edilecekse; öncelikle uygun toprak ıslah yöntemi alana uygulanmalı ve daha sonra toprakların tuz içeriğine bağlı olarak yetiștirilecek ürün tavsiye edilmelidir. Toprak etüt ve haritalama çalıșmalarında uzaktan algılama ve coğrafi bilgi sistemleri teknolojisinin kullanılması hem zaman hem de ekonomik anlamda önemli avantajlar sunmaktadır. Özellikle seri ve seriler içinde tanımlanan fazların sınırlarının kesinleștirilmesinde uydu görüntüsü kullanımı çok önemli kolaylıklar sağlamaktadır. CBS teknolojisi kullanılarak olușturulan haritalar ise bir çok analizin yapıımasına imkan verdiği gibi, daha sonra gerçekleștirilecek çalıșmalara da altıı sağlamaktadır. 
Bu çalıșma ile 3868,8 ha yüzölçümüne sahip bir alanın detaylı toprak etüt ve haritalama çalıșması gerçekleștirilmiștir. Ülkemizde toprak kaynaklarının envanterlerinin belirlenmesi için bu tür çalıșmaların dikkate alınması ve önem verilmesi gerekmektedir. Lokal ve bölgesel alanlardan ziyade, Türkiye'yi kapsayacak etüt çalıșmalarının yapılması toprak kaynakları hakkında detaylı, izlenebilir bir veriye sahip olunmasını sağlayacaktır.

\section{KAYNAKLAR}

Akgül M, Bașayiğit L (2005). Süleyman Demirel Üniversitesi ciftlik arazisitopraklarının detaylı etüt ve haritalanması. Süleyman Demirel Üniversitesi, FenBilimleri Enstitüsü Dergisi, 9-3.

Bouyoucos G S (1951). A recalibration of the hydrometer method for making mechanical analysis of soils. Argon. Jour., 43: 434-448

Dengiz O, Öztürk E, Sarıoğlu E (2010). Alüviyal tașkın ovada morfometrik esaslara göre toprakların sınıflama ve haritalama çalıșması; Çarșamba-Dikbıyık Beldesi, 1. Ulusal Toprak ve Su Kaynakları Kongresi, 351-361, Eskișehir.

Grewelling T, Peech M (1960). Chemical Soil Test. Cornell University Agr. Expt. Sta. Bull., 960.

MGM (2014). Devlet Meteoroloji İșleri Müdürlüğü, Çanakkale Meteoroloji Müdürlüğü kayıtları. Erișim: http://www.mgm.gov.tr (01.06.2015).

Kayan i (2000). The water supply of Troia. Studia Troica verlag philipp von zabern, mainz am rhein, pp. 135-144.
Krauss M J (1999). Paleosols in clastic sedimentary rocks: their geologic applications. Earth-Science Reviews, 47: 41-70.

Richards LA (1954). Diagnosis and improvement of saline and alkali soils. U.S. Department of Agriculture Handbook, 60: 94

Saygın F, Dengiz O (2013). Bafra Ovası sol sahilinde yer alan Fener Köyü ve yakın çevresinde dağılım gösteren farklı toprakların sınıflandırıması ve dağıım alanlarının belirlenmesi. Toprak Su Dergisi, 2 (2): 63-72.

Schlichting E, Blume, E (1966). Bodenkundliches Practikum. Verlag Paul Parey, Hamburg und Berlin, p.209.

Smith H W, Weldon M D (1941). A comparison of some methods for the determination of soil organic matter. Soil Science Society American Proceeding, 5: 177-182.

Soil Survey Staff (1999). Soil Taxonomy. A basic of soil classification for making and interpreting soil survey. USDA Handbook, 436, Washington D.C.

Soil Taxonomy (2014). Soil Survey Staff, Keys to Soil Taxonomy, 12th ed. USDA-Natural Resources Conservation Service, Washington, DC.

US Salinity Laboratory Staff (1954). Diagnosis and improvement of saline and alkali soils. USDA Handbook 60, U.S. Government Printing Office, Washington, D. C.

WRB (2006). World Reference Base for Soil Resources, World Soil Resources Reports, 103, FAO, Rome.

WRB (2014). World Reference Base for Soil Resources, World Soil Resources Reports, 106, FAO, Rome. ISBN 978-925-108369-7 